The National Library supplies copies of this article under licence from the Copyright

Agency Limited (CAL). Further reproductions of this

article can only be made under licence.

\title{
Separation Anxiety in Three of Gillian Rubinstein's Collaborative Picture Story Books
}

Alice Mills

7 illian Rubinstein is one of the most versatile contemporary Australian writers for children. She has written realist problem novels, speculative fiction and fantasy, and has won literary awards for both her realist and science fiction writings. She has published fiction in the extended narrative form of the novel for young adults, shorter novels for younger readers, short stories and picture story books (one of which is almost wordless). Some of her fiction is experimental: the alternative endings to Beyond the Labyrinth, for instance, and the alternating conventional prose narrative and picture story book sections of The Giant's Tooth. Critical attention has so far been focussed on her works for older readers rather than the collaborative picture story books, despite Mr Plunkett's Pool winning the Australian Multicultural Children's Book Award and Dog In Cat Out being short-listed for the Children's Book Council of Australia Book of the Year Award.

To discuss the picture story books in which she is a collaborator, is to raise the vexed question of attribution: how much of the book can be attributed to Rubinstein and how much to the illustrator? To take the extreme example of Dog In Cat Out, a book with a total vocabulary of only four words, 'dog', 'cat', 'out' and 'in', it might seem that all the book's inventive detail derives from the illustrator; but the equal listing of author Rubinstein and illustrator Ann James on the front cover suggests a much more equal contribution from each. The problem of attribution recurs in discussing each of Rubinstein's picture story book collaborations. In each case I propose to treat the book as a fully collaborative product. Thus Dog In Cat Out is both a James-mediated segment of Rubinstein's oeuvre and (in the context of a different critical study) a Rubinstein-mediated segment of James' oeuvre.

Like many other picture story books, several of Rubinstein's collaborative works explore child development either overtly or by presenting talking animals as child figures. Keep Me Company (with Lorraine Hannay) and the two Jake and Pete books (with Terry Denton) can be understood as exploring aspects of child psychology, with particular emphasis on separation anxiety. As defined by Bowlby in his authoritative studies of separation anxiety, Attachment and Separation: Anxiety and Anger, separation anxiety is that state 'so readily engendered whenever a small child is separated for long from his mother figure' (Bowlby 1975, p.23) and its best cure is a speedy reunion with the mother or mother figure. According to Bowlby, separation anxiety is first evident when a child is about 28 weeks old, and it remains intense until at least the third birthday. The loss, or prolonged absence of a mother figure has profound and long-lasting ill effects upon the young child, Bowlby argues, and he detects symptoms of anxiety, hostility, fear and neediness in children even when the absence is very brief.

Of all Rubinstein's collaborative picture story books, Keep Me Company offers the most straightforward treatment of this theme. In complementary words and pictures the book presents the unhappiness of a young girl, Marnie, ill with chicken pox, unwilling to eat or to rest, demanding to keep her mother company rather than stay in bed alone. In all the illustrations Marnie seems rather a large child to be still in the grip of intense separation anxiety. Her size suggests that she is between four and six years old, in which case her need for her mother's company can be viewed as regressive behaviour brought about by the stress of illness.

In Keep Me Company the child's insistence on keeping her mother company is used to coax her into eating when her mother eats and sleeping when her mother lies down on the bed. By the end of the book Marnie is well enough to 'keep Mum and Dad company all evening' - the much desired goal of many small children who do not want to be left alone in the bedroom. The corresponding 
illustration shows the child sitting happily on her mother's knee, both parents paying her close attention. The picture emphasizes Mum, not Dad. She is shown full face, while most of his face is hidden as he looks sideways, head bent. Mother, father and child are depicted in a harmoniously curved grouping reminiscent of a multitude of Holy Family paintings where the beloved child in mother's arms is the focus of all attention, while the father worships from a subordinate position. Such a configuration in Keep Me Company could be regarded as relieving the child's separation anxiety, with Mum available, attentive and physically close throughout the evening. This would represent Bowlby's ideal immediate answer to separation anxiety, the child's secure reunion with mother.

An alternative interpretation of the book's ending, more optimistic still, could also be argued from a Bowlbian point of view. While reunion with the mother is his answer to separation anxiety's symptoms, Bowlby also discusses the child's development past the stage of attachment to the mother only. He is markedly more optimistic than Freud, and gives no attention to the Oedipal complex as the next stage of child development. Instead, the child's healthy development, according to Bowlby, is a matter of moving from passionate attachment to the mother only, towards a secure connection with both father and mother. Analyzed in these terms, Marnie's close companionship with both parents can be read as a sign of her development beyond regression, towards a more secure attachment to both parents. Either reading is supported by the details of the page. The preferred reading, in psychoanalytic terms, in part depends on the child reader's own developmental stage, and on any unresolved early childhood issues for the older reader.

Like the final family grouping of Keep Me Company, Marnie's behaviour towards her doll throughout the book is quite closely in accord with Bowlby's theory. The series of illustrations of Marnie's doll can be read in several ways, depending on the emphasis given to Marnie as the doll's symbolic mother, to the doll as a symbol of the child, and to the doll's gender and pirate costume. As with Marnie's family grouping, the meanings of each doll image are over-determined, as the child plays simultaneously through her separation anxiety and her relationships with both mother and father.

Most obviously, Marnie's treatment of her doll suggests that she is dealing with separation anxiety through symbolic play. The book's first illustration depicts a solitary doll lying on its back. The doll's smiling mouth is cancelled out by a superimposed long black moustache; the doll's position carries overtones of human vulnerability and fear. This picture is balanced by the final illustration of Marnie lying back in her bed cuddling the same doll. The difference in the doll's location corresponds with the change in Marnie's physical and emotional states. As Marnie finds comfort and reassurance in her mother's arms, the doll is shown in Marnie's arms. The child displaces her separation anxiety onto the doll: symbolically, the doll is Marnie.

Her play is more complex than this, however. Marnie herself initially throws away her doll ('She didn't want to play with her toys'), acting out the role of her mother as perceived by the unhappy child. In throwing out, then cuddling the doll, Marnie is coming to terms with her mother's absence and perceived rejection. The child thus introjects, becoming first the rejecting and then the loving mother in symbolic play.

The doll as pirate is well fitted, as an adult figure of lawlessness, defiance and travel, to embody Marnie's refusals to please her mother by eating or resting in bed, Marnie's longing to leave her bedroom, even the anger that Marnie herself expresses by sulking. The pirate is also well 
fitted to embody any fear the child may have that she is wicked, that her mother's absence is due to her own naughtiness. These qualities of Marnie's doll are latent rather than realized in the book, available for any child reader who may be struggling with guilt, hostility and anger towards a real-life mother. Bowlby also speaks of the child's wish to punish the mother for her absence; this desire is also symbolically catered for, as it is an adult doll that Marnie throws away.

To complete a Bowlbian analysis of Marnie's play, the doll's masculinity must be taken into account. The child first rejects, then cuddles an adult male figure in the form of a toy. Her play can be understood in this regard as encompassing her feelings towards her father. If Bowlby is correct in his theorizing, the covert message to her father would be, 'If only Mum would reject him instead of me! Only when I am sure that Mum loves me can I make room in the cuddles for Dad.'

While Bowlby's theory of separation and attachment offers a helpful context for much of Keep Me Company, aspects of the picture story book remain outside his theoretical framework. The final scene, for example, where Marnie lies happily on her bed holding the pirate doll close to her, could be interpreted in a more orthodox Freudian fashion as representing the child's Oedipal desire for her father. Such a desire would be more appropriate to her age, according to classical psychoanalytic theory, than acute separation anxiety and desire for the mother.

Bowlby is silent on the topic of the Oedipal complex, nor does he theorize the body. There are several unusual representations of bodies in Keep Me Company, including the oddly pock-free midriff of Marnie herself in the early illustration where she lifts up her pyjama top to touch herself ('Marnie had chicken pox and it made her grumpy and itchy'). She does, however, have a massive belly button suggestive of a childhood hernia - unless this roundish red swelling is a single enormous pock mark. A navel that is all one itchy swelling, indicative of illness, would be a very apt symbol of separation anxiety, situated as it is at the point where the chidd's physical connection with the mother was severed at birth.

Marnie's pirate doll wears a patch over one eye; in both their appearances her other toys, two stuffed animals, are shown in part only, each with a single eye visible. As Marnie becomes more well and happy, the pirate doll's face becomes more concealed. None of these details fits into the comforting overt narrative of the book. The child's body, against all medical likelihood, recovers from chickenpox through access to her mother; meanwhile, in the subtext, her toys lose their faces more and more. It is as though the little girl's sickness and distress have not been healed, merely displaced onto the fragmented and faceless bodies of her toys.

In Keep Me Company, the toys' faces could perhaps be dismissed as a trivial set of oddities; in the two Jake and Pete books, the main characters' faces are emphasized in both picture and word as extraordinarily defective. According to both books' cover illustrations, the kittens Jake and Pete have enormous heads with wide open, red-lipped humanoid mouths, each boasting only two teeth. According to the written text, Jake is born lacking the ability to smell, and his twin Pete has poor eyesight. They are ill equipped to survive, even working together to catch their prey. In their helpless dependence on their mother, Jake and Pete are very like young human children. The choice of smell and sight as their defective senses means that they are even more humanized, like humans unable to hunt by smell, like humans prone to poor eyesight, remaining dependent on a mother figure long after real life kittens do. Their vulnerabilities leave them prone to acute separation anxiety. In the course of the Jake and Pete series, loss of 
a mother figure, intense and prolonged separation anxiety and eventual secure attachment, recur as a sequence at least three times.

The first Bowlbian catastrophe occurs when the mumcat decides to leave the home barn. 'Kits, I am getting old. I am going to retire. I'm going to find Home with mice person and big fridge' (Rubinstein \& Denton 1995, p. 10). This last sentence aligns the mother with her kittens. She too is in need of a home where she will be fed and cared for. Words like 'old' and 'retire' indicate that she is relinquishing her role as mother, in effect dying as a nurturer and provider for her children, in order to take up the role of nurtured infant herself.

The kittens almost die when she has left. Their plight, lacking their mother and unable to feed themselves, is a separation emergency.

Jake and Pete's plight worsens when a new cat moves into the barn. He is perhaps the kitkids' biological father, and at first glance he seems to be fulfilling a human father's stereotypical role of providing food for his children.

It had already killed five mice and two rats. They were lined up on the floor.

'Looks like dinner,' miaowed Jake.

'Smells like dinner,' purred Pete.

'Get lost, little puddies,' yowled the huge ginger tomcat.

(RubinsteinandDenton 1995,p.13)
The kitkids, with a tenuous hold on life now that their mother has abandoned them, are now threatened with death by the tomcat. Their separation anxiety is at its most extreme.

As with Keep Me Company, an analysis of Jake and Pete can be extended beyond Bowlby's limits to include the Oedipal complex, as the next stage of child development. With mother unavailable and this terrible father figure menacing them with tooth and claw, the children are being bullied out of their maternal home. The rivalry between murderous father and mother-loving child is blatant. The battle is resolved in the tomcat's favour, as the two kittens are forced out of the neighbourhood. In this round of play, then, the Oedipal contest between father and son seems likely to end in the kittens' death, until the life-saving intervention of their rescuer, Bog the boggart.

\section{In Jake and Pete and the Stray}

Dogs, the problem of separation anxiety is restated in milder terms in the story of two new characters, the lost dogs, Laddie and Lass. The dogs become disoriented when their family moves house. Their names allude to Lassie, the dog who can miraculously find her way home, and also identify them as symbolic children, any lass and any lad. Unlike Jake and Pete in the first book, the dogs have a secure home to return to, and they are eventually reunited with their family.

Jake and Pete also find a happy ending in both books, united with a new mother figure, Bog the boggart. Bog is the answer to all their dreams and hopes of a home, at the end of the first book, Jake and Pete. At the end of the second book, when the kitkids have found their lost birthmother and at least one of them has the opportunity to stay with her and leave his twin and the boggart, both Jake and Pete ultimately decide to stay together with Bog. While Laddie and Lass find a temporary refuge with Bog in his home underground in the drains, Jake, Pete and Bog make up a more permanent family group, for he offers them food, warmth and companionship, and is an ideal mother substitute; moreover, the kitkids find a purpose and function with him that were deficient either with their mother or on their own. Both books end joyfully with the kitkids and Bog living together as 'best friends and a happy family' (Rubinstein and Denton 1997, p.75)

There is, however, a darker subtext to this much told story of separation anxiety and secure attachment. It is most obvious in the case of Lass and Laddie, the lost dogs who are swept into the drain when a creek rises in heavy rain, and who are saved by Bog from drowning. All the animals' lives in the drain are variants on 
the common fate of small unwanted domestic animals, to be drowned in river or drain or flushed down the toilet. Bog's toilet name hints strongly at this reading. Both books could thus be read as Rubinstein and Denton's compensatory fantasy, inverting the reality of drowned puppies and kittens that are lost, physically defective or simply unwanted. In so far as the books explore a child's separation anxiety by way of the animals' troubles, the happy endings are a fragile fiction. The mother cat makes the point to her kitkids, once in each book. When she tells them that she is retiring to a Home, she explains why they cannot accompany her:

'It is a fact of the catlife,' the mumcat replied sadly, 'that one cat is a pet but three are pests.' (Rubinstein and Denton 1995, p.10).

Jake and Pete and the Stray Dogs is much milder in tone, and when the kittens eventually find their mother, the human mother in the house plans to find them another new home. Their biological mother, however, still regards them as vermin:

'As I've told you before, one cat is a pet, even two cats can be pets, but three cats are definitely pests.' (Rubinstein and Denton 1997, p.71). These are her last words to her children in the book, reiterating rejection, exclusion and the threat of death.

These three books, then, are much more ridden with anxiety, loss and death than a casual reading might reveal. Read in order of publication, they steadily darken in tone. Keep Me Company displaces its miseries onto the dolls, and Marnie's unhappiness is brief. The two Jake and Pete books speak openly of the pains and terrors of the child who has lost his mother, the anguish of being deliberately abandoned. They only hint at an even darker reading, in which a rejecting mother flushes her unwanted children down the toilet to death.

\section{$\rightarrow 29 \cdot: E K$}

\section{References}

Bowlby, John (1971) Attachment. Penguin, Harmondsworth.

Bowlby, John (1975) Separation: Anxiety and Anger. Penguin, Harmondsworth.

Rubinstein, Gillian and Denton, Terry (1995) Jake and Pete. Random House, Sydney.

Rubinstein, Gillian and Denton, Terry (1997) Jake and Pete and the Stray Dogs. Random House, Sydney.

Rubinstein, Gillian and Hannay, Lorraine (1992) Keep Me Company. Viking, Ringwood.

\section{Biographical Note}

Alice Mills is a senior lecturer in literature and children's literature at the University of Ballarat. Her research interests include fantasy, myth and picture story books . She has published widely in the field of children's literature, and has recently edited the Random House Children's Treasury.

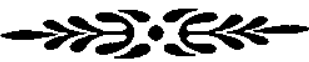

